\title{
Consistent: the Convention on the Protection of the Underwater Cultural Heritage and the United Nations Convention on the Law of the Sea
}

\author{
Vincent P Cogliati-Bantz \\ Craig J S Forrest ${ }^{\dagger}$
}

\begin{abstract}
The Convention on the Protection of the Underwater Cultural Heritage, adopted in 2001, addresses rights, jurisdiction and duties of States in the various maritime zones set out in the United Nations Convention on the Law of the Sea. This article argues that the manner in which the Convention on the Protection of the Underwater Cultural Heritage does so is compatible and consistent with the United Nations Convention on the Law of the Sea and that there exists, in this respect, no international barrier hindering broad state participation in this important protective regime.

\section{Keywords}

Convention on the Protection of the Underwater Cultural Heritage, United Nations Convention on the Law of the Sea, maritime zones, state jurisdiction, wrecks
\end{abstract}

\section{Introduction}

The $100^{\text {th }}$ anniversary of the sinking of the RMS Titanic has focussed the world's attention on the rich reservoir of maritime heritage that lies beneath the oceans. On this anniversary this iconic wreck was embraced by the protective mantel

\footnotetext{
Senior Lecturer, TC Beirne School of Law (Marine and Shipping Law Unit, University of Queensland.

+ Associate Professor, TC Beirne School of Law (Marine and Shipping Law Unit), University of Queensland; Member of the South African Delegation to the UNESCO Meeting of Experts to Draft the Convention on the Protection of the Underwater Cultural Heritage, 1998-2000.
}

Copyright $\odot$ the Author(s).

This work is licensed under a Creative Commons Attribution-NonCommercial-NoDerivs 3.0 License. 
of the 2001 Convention on the Protection of the Underwater Cultural Heritage (UCHC). ${ }^{1}$ For those states with an interest in the vessel, such as the United States, Canada, and its flag state, the United Kingdom, ${ }^{2}$ this prospect raises possible jurisdictional issues and brings into question the extent to which the UCHC can be applied in the context of the United Nations Convention on the Law of the Sea (UNCLOS). ${ }^{3}$ This article argues that the UCHC is compatible with UNCLOS and thus no barrier to participation in this important protective regime ${ }^{4}$; a view which is apparently supported by the General Assembly of the United Nations which, in its 2011 Resolution on Oceans and the Law of the Sea, noted:

the recent deposit of instruments of ratification and acceptance of the 2001 Convention on the Protection of the Underwater Cultural Heritage, calls upon States that have not yet done so to consider becoming parties to that Convention, and notes in particular the rules annexed to that Convention, which address the relationship between salvage law and scientific principles of management, conservation and protection of underwater cultural heritage among Parties, their nationals and vessels flying their flag. ${ }^{5}$

\section{The 1982 United Nations Convention on the Law of the Sea}

UNCLOS provided, prior to the adoption of the UCHC, the only substantive international law relating to underwater cultural heritage $(U C H)$. This substantive law is contained in only two Articles: 149 and 303.

1 Convention on the Protection of the Underwater Cultural Heritage, 2 November 2001, [2002] 41 ILM 40.

2 A Ruffman, I T Gault \& D VanderZwaag, 'Legal Jurisdiction Over the Titanic' (1988) 37 Lighthouse 23.

3 United Nations Convention on the Law of the Sea, 10 December 1982, 1833 UNTS 396.

4 A W Gonzalez, 'Negogiating the Convention on Underwater Cultural Heritage: Myths and Reality' in R Garabello \& T Scovazzi (eds), The Protection of Underwater Cultural heritage: Before and After the 2001 UNESCO Convention (2003) 116-21; S Dromgoole, 'Reflections on the Position of the Major Maritime Powers with Respect to the UNESCO Convention on the Protection of the Underwater Cultural Heritage 2001' (2013) 38 Marine Policy 116.

5 Ocean and the Law of the Sea, GA Res 66/231, 24 December 2011. 


\subsection{Article 149}

Article 149 reads:

All objects of an archaeological and historical nature found in the Area shall be preserved or disposed of for the benefit of mankind as a whole, particular regard being paid to the preferential rights of the state or country of origin, or the state of cultural origin, or the state of historical and archaeological origin. ${ }^{6}$

This Article introduces two key notions concerning the protection of $\mathrm{UCH}$. Firstly, that the protection of $\mathrm{UCH}$ is for the benefit of mankind and secondly, the notion of preferential rights of certain states.

It has been difficult to reach consensus on the interpretation of this Article. In particular, it does not specify the manner in which objects of an archaeological and historical nature are to be 'preserved or disposed of', nor does it explain who will provide the necessary funding for the preservation or disposal. ${ }^{7}$ Preservation may mean in situ preservation, placement in a museum, or delivery from marine peril as defined in salvage law. ${ }^{8}$ Similarly, disposal may refer to the removal of these objects in order to recover natural resources beneath them ${ }^{9}$ or disposal by way of recovery and either sale or placement in a museum. ${ }^{10}$ If the benefits of disposal of UCH are viewed as economic, it may mean that artefacts themselves could be divided up between states or that the funds derived from displaying artefacts so divided up. Alternatively, within the context of cultural heritage management, 'benefit to mankind' may refer to the intangible aspect of learning from these objects and understanding the common past of humankind.

6 UNCLOS Art 1(1) defines the Area as the 'sea-bed and ocean floor and subsoil thereof, beyond the limits of national jurisdiction' (i.e. beyond the continental shelf).

7 A Strati, The Protection of the Underwater Cultural Heritage: An Emerging Objective of the Contemporary Law of the Sea (1995) 300.

8 L Migliorino, 'In Situ Protection of the Underwater Cultural Heritage under International Treaties and National Legislation', (1995) 10 International Journal of Marine and Coastal Law 483, 486. See also C F Newton, 'Finders Keepers? The Titanic and the 1982 Law of the Sea Convention' (1986) 10 Hastings International and Comparative Law Review 159; C J S Forrest, 'Has the Application of Salvage Law to Underwater Cultural Heritage Become a Thing of the Past?' (2003) 34 JMLC 309.

9 L V Prott \& P J O’Keefe, Law and the Cultural Heritage: Discovery and Excavation (1984) 98.

${ }^{10} \mathrm{~S}$ Dromgoole, Law and the Underwater Cultural Heritage: A Legal Framework for the Protection of the Underwater Cultural Heritage in the United Kingdom (PhD Thesis, University of Southampton, 1993) 4-39. 
The second issue of interpretation lies in the 'preferential rights' to be given to a number of alternative states. It is difficult to determine which of the alternative states should have preferential rights. ${ }^{11}$ The distinction between a 'state of origin', a 'state of cultural origin', 'a state of historical origin' and a 'state or archaeological origin' is not spelled out and it is unclear whether the latter three are sub-categories of the former. ${ }^{12}$ A 'state of origin', for example, may refer to the state where the object was manufactured or the flag state of the vessel on which the object was carried. A 'country of origin' may refer to an entity no longer extant, and gives rise to issues of state succession.

The uncertainties regarding the possible economic disposal of $\mathrm{UCH}$ and the ambiguities regarding states' preferential rights impairs the application of the concept of the common heritage of mankind to UCH found in the Area. The vagueness and ambiguity of Article 149 leaves it with little operational normative content, and has led one commentator to refer to it as essentially hortatory in nature given the absence of the kind of craftsmanship normally found in texts dealing with complex issues of title to property. ${ }^{13}$

\subsection{Article 303}

Article 303 reads:

1. States have the duty to protect objects of an archaeological and historical nature found at sea and shall cooperate for this purpose.

2. In order to control traffic in such objects, the coastal State may, in applying Article 33, presume that their removal from the seabed in the zone referred to in that Article without its approval would result in an infringement within its territory or territorial sea of the laws and regulations referred to in that Article.

3. Nothing in this Article affects the rights of identifiable owners, the law of salvage or other rules of admiralty, or laws and practices with respect to cultural exchanges.

${ }^{11}$ ILA Sixty-Fourth Conference, Report of the International Committee on Cultural Heritage Law, Queensland, Australia (1990) 8.

${ }^{12}$ L Caflisch, 'Submarine Antiquities and the International Law of the Sea' (1982) 13 NYIL 3, 30.

${ }^{13}$ B H Oxman, 'Marine Archaeology and the International Law of the Sea' (1988) 12 Columbia VLA Journal of Law and the Arts 353, 361. 
4. This Article is without prejudice to other international agreements and rules of international law regarding the protection of objects of an archaeological and historical nature.

The sweeping duty contained in Article 303(1) is formulated similarly to Article $192^{14}$ but is not accompanied by the kind of provisions in Part XII, which specify more precisely the nature and the scope of the duties in relation to the marine environment. ${ }^{15}$ UNCLOS does not define the scope of this duty, nor its object, nor is there a basis upon which protective measures can be defined in the absence of any applicable international instrument. As such, it has been suggested that it 'appears far too general and vague to have any significant normative content'. ${ }^{16}$ It may mean in situ preservation, an obligation not to damage or destroy $\mathrm{UCH}$, or perhaps raising $\mathrm{UCH}$ to preserve it from marine peril. ${ }^{17}$ However, at the very least it imposes a duty to cooperate towards the formulation of further international standards of protection. As Article 303(1) applies to all maritime zones ('found at sea'), the exercise of this must be consistent with UNCLOS.

Article 303(2) allows the coastal state to presume that removal of $\mathrm{UCH}$ in the contiguous zone $(C Z)$ without its approval would result in an infringement within its territory or territorial sea of its customs, fiscal, immigration or sanitary laws and regulations, which that state is permitted to prevent and punish under Article 33 and to exercise the necessary control in the $\mathrm{CZ}$ to that effect.

Since this presumption operates as a legal fiction, ${ }^{18}$ should the state wish to regulate the removal of $\mathrm{UCH}$ in the $\mathrm{CZ}$, it may extend the effect of the laws and regulations covered by Article 33. ${ }^{19}$ Unauthorised removal of UCH may ipso facto be considered an infringement of customs, fiscal, immigration or sanitary laws applicable within the territory or territorial sea of the coastal state. This presumption is not rebuttable, not only because the text of Article 303(2) does not mention rebuttability but also because it would defeat the very purpose of Article 303. ${ }^{20}$ The coastal state may impose conditions related to the removal of UCH

\footnotetext{
${ }^{14}$ UNCLOS Art 192 provides that 'States have the obligation to protect and preserve the marine environment'.

${ }^{15}$ E.g. UNCLOS Art 194(2).

${ }^{16}$ Caflisch, above n 12, 20.

17 P J O'Keefe \& J Nafziger, 'The Draft Convention on the Protection of the Underwater Cultural Heritage' (1994) 25 Ocean Development and International Law 393; Migliorino, above n 8, 486; Newton, above n 8, 193.

${ }^{18}$ In relying on this fiction, the coastal state must have designated a CZ.

${ }^{19}$ Caflisch, above n 12, 20.

${ }^{20}$ Strati, above $\mathrm{n} 7,167$.
} 
from the seabed of the CZ. ${ }^{21}$ Article 303(2) does not, in itself, apply to activities such as diving on a wreck, filming a wreck, or in some way damaging a wreck. ${ }^{22}$ However, the duty imposed in Article 303(1) may touch on these issues. Given that Article 303(1) in itself does not favour the coastal state, its impact on the coastal state's competence in the CZ must be addressed by international agreement under Article 303(4). ${ }^{23}$

Article 303(3) means that the protection of UCH by states under paragraph 1 does not affect the rights of identifiable owners, the law of salvage or other rules of admiralty, or laws and practices with respect to cultural exchanges. These laws are left out of the purview of Article 303, and there is simply no intent to address these in any way and, therefore, all existing uncertainties remain. ${ }^{24}$

Article 303(4) 'leaves the way open for specific agreement on the underwater cultural heritage.25 It was intended that Article 303(4) would harmonise the rules of the law of the sea on UCH with the emerging law of archaeology and cultural heritage. $^{26}$

\subsection{The scope and relationship of Articles 149 and 303}

A problem arises with the scope of Article 303, which was included in Part XVI of UNCLOS entitled 'General Provisions'. Since paragraphs 1, 3 and 4 of Article 303 apply to all maritime zones, they may overlap with the provisions in Article 149 on the Area. There is no genuine conflict between Article 303(1) and Article 149 if the latter is regarded as the lex specialis way of protecting UCH found in the Area. However, although Article 303 does not prejudice other international agreements and rules of international law, no equivalent provision to paragraph 4 is found in

${ }^{21}$ For example, France and Tunisia have extended their heritage legislation over the CZ: Act Concerning Marine Cultural Property 89-874 of 1 December 1989 (France) and Protection of Archaeological Property, Historic Monuments and Natural Urban Sites Law No 86-35 of 9 May 1988 (Tunisia). See K G Lee, 'An Inquiry into the Compatibility of the UNESCO Convention 2001 with UNCLOS 1982' in LV Prott (ed), Finishing the Interrupted Voyage. Papers of the UNESCO Asia-Pacific Workshop on the 2001 Convention on the Protection of the Underwater Cultural Heritage (2006), 21.

${ }^{22}$ See Newton, above n $8,187$.

${ }^{23}$ See below.

${ }^{24}$ On these issues, see D J Bederman, 'Rethinking the Legal Status of Sunken Warships' (2000) 31 Ocean Development and International Law 97; C J S Forrest, 'An International Perspective on Sunken State Vessels as Underwater Cultural Heritage' (2003) 34 Ocean Development and International Law 41.

${ }^{25}$ Prott \& O’Keefe, above n 9, 105.

${ }^{26}$ Oxman, above n 13, 364. 
Article 149. Hence for Caflisch, a conflict might arise. ${ }^{27}$ If some states entered into an agreement on the protection of $\mathrm{UCH}$ found in the Area which would not respect the clause on the benefit of mankind as a whole or the preferential rights of certain states, this would have to be regarded as a modification of UNCLOS incompatible with a basic principle embodied therein, in contravention of Article 311(3).

On the other hand, a genuine conflict could occur between the operation of Article 303(3) and Article 149. Dromgoole, for example, argues that, as Article 303(3) specifically leaves the law of salvage unaffected, UCH may have to be disposed of in order to pay the salvage award but Article 149 specifies that the disposal shall be for the benefit of mankind as a whole. ${ }^{28}$ Caflisch resolves the conflict in favour of Article 303(3), arguing on the basis of the lack of general effectiveness of the regime proposed in Article $149 .^{29}$ Strati correctly adopts the opposite view, considering the lex specialis nature of Article $149 .{ }^{30}$

\section{UNESCO Convention on the Protection of the Underwater Cultural Heritage}

It is apparent that in an attempt to reach consensus on the package deal that is UNCLOS, Articles 149 and 303 were left vague and ambiguous as their drafting was inconsequential compared to the major issues then being addressed. ${ }^{31}$ The need for a comprehensive international regime for the protection of $\mathrm{UCH}$ has therefore long been evident. Whilst threats to this valuable but limited historical and archaeological resource, such as harbour dredging, land reclamation schemes, pipeline construction, deep seabed mining, oil and gas exploration and fishing activities, are unintentional, other activities, particularly those of salvors or 'treasure hunters', are not.

The UCHC originated from a draft produced by the International Law Association's (ILA) in 1994. ${ }^{32}$ The ILA approach to the problem was characterised by two strategies that substantially mirrored a previous attempt at adopting a

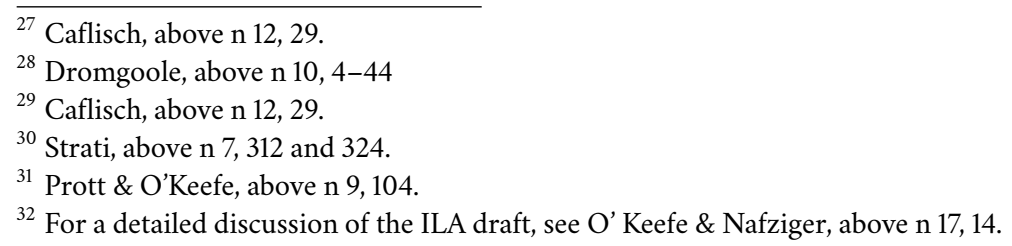


European Convention to protect $\mathrm{UCH}^{33}$ First, it provided for the creation of a cultural heritage zone up to 200 nautical miles $(\mathrm{nm})$; and secondly, admiralty and salvage law was to be excluded. Annexed to the draft was the Charter on the Protection and Management of Underwater Cultural Heritage produced by the International Council of Monuments and Sites, ${ }^{34}$ which sets out benchmark standards for underwater archaeology. As the ILA is a non-governmental organisation, UNESCO was a more appropriate organisation to further the development of the convention.

The ILA draft convention was an integration of aspects of three spheres of law: cultural heritage law, admiralty law and the law of the sea. The latter was of particular concern, especially in relation to the possibility of conflict with UNCLOS. ${ }^{35}$ Unfortunately it became very difficult to obtain consensus on the interpretations of a number of the provisions of UNCLOS raised by the draft. Not only did negotiations then shift from cultural heritage issues to law of the sea issues, ${ }^{36}$ but UNESCO's appropriateness as a forum for negotiation on issues concerning the law of the sea was brought into question. ${ }^{37}$ The proposed jurisdictional regime also unleashed an array of political issues unresolved in other international fora, including the question of maritime delimitation, the extent of the coastal states' jurisdiction over the exclusive economic zone (EEZ) and continental shelf (CS), and the importance of UNCLOS itself. At times, negotiations resembled similar negotiation leading to UNCLOS, with the same states proposing the extension of coastal state jurisdiction with regard to $\mathrm{UCH}^{38}$ and the same states opposing such a regime ${ }^{39}$, leading to accusations that the UNESCO proposal was being used as a mechanism for re-opening UNCLOS negotiations. The result was a very real concern that the UCHC be designed so as to be consistent with UNCLOS. ${ }^{40}$ These concerns were reiterated by the

\footnotetext{
${ }^{33}$ For further detail on the European draft Convention, see J Blake, 'The Protection of the Underwater Cultural Heritage' (1996) 45 ICLQ 819, 820-27.

${ }^{34} \mathrm{~A}$ non-governmental organisation with special observer status at UNESCO whose primary function is to provide advice on the steps necessary to conserve the monuments and sites of the world.

${ }^{35}$ Doc 141 EX/18 Paris, 23 March 1993, Resolution 5.5.1, para 20.

${ }^{36}$ Gonzalez, above $n$ 4, 84.

${ }^{37}$ P J O'Keefe, 'Second Meeting of Governmental Experts to Consider the Draft Convention on the Protection of Underwater Cultural heritage' (1999) 8 International Journal of Cultural Property 569.

${ }^{38}$ Such as Greece and Turkey: ibid, 119-20.

${ }^{39}$ Such as the Netherlands, UK and the US: ibid, 117.

${ }^{40}$ Ibid, 117.
} 
UN General Assembly which, in November 1998, stressed the importance of ensuring that the instrument to be elaborated [be] in full conformity with the relevant provisions of the Convention.' ${ }^{41}$

Given the difficulties of addressing coastal state jurisdiction and the impasse created at the end of negotiations in 1999, a proposal was made that concentrated on the areas of co-operation, notification and collaboration, that were generally non-contentious issues, and could form the foundation on which a shared jurisdiction structure could be built. This was ultimately successful and the resulting UCHC takes as its starting point the general principles found in Articles 149 and 303 of UNCLOS that states have a duty to protect UCH for the benefit of mankind, and are required to co-operate for this purpose. ${ }^{42}$ It was noted, however, that the protective regime required strengthening and the first general principle of the UCHC provides that its aim is 'to ensure and strengthen the protection of underwater cultural heritage. ${ }^{43}$ That was to be achieved by the introduction of a set of archaeological standards for excavation so as to ensure not only the physical integrity of UCH but to preserve the archaeological value that it embodies. To this end, Article 2(7) declares that UCH 'shall not be commercially exploited' while Article 4 substantially limits the application of the law of salvage. ${ }^{44}$ It was recognised that any international protection regime will only be effective if there is sufficient cooperation between states. ${ }^{45}$ Furthermore, the principle of cooperation was not restricted to states, but requires cooperation between interest groups such as scientific institutions, archaeologists and divers. ${ }^{46}$ The actual protective regime is based on the jurisdictional competence of individual states, requiring each state to undertake to preserve $\mathrm{UCH}$ that falls within its competence in a prescribed manner in

\footnotetext{
${ }^{41}$ Oceans and the Law of the Sea, GA Res 53/32, 24 November 1998, para 20.

${ }^{42}$ The duty to cooperate is evident in the preamble's $10^{\text {th }}$ recital and Arts 2(2) and 19 of UCHC.

${ }^{43}$ UCHC Art 2(1).

${ }^{44}$ UCHC Art 4 provides that:
}

[a]ny activity relating to underwater cultural heritage to which this Convention applies shall not be subject to the law of salvage or law of finds, unless it: (a) is authorized by the competent authorities, and (b) is in full conformity with this Convention, and (c) ensures that any recovery of the underwater cultural heritage achieves its maximum protection.

\footnotetext{
${ }^{45} \mathrm{UCHC}$ Arts 2(2) and 2(4).

${ }^{46}$ UCHC Art 2(10) promotes '[r] esponsible non-intrusive access to observe or document in situ underwater cultural heritage'.
} 
the interests of humankind. Thus each state is required, inter alia, to establish educational and national services to preserve $\mathrm{UCH}$, to impose sanctions for breaches of prescribed duties, to ensure that the benchmarking standards are adhered to and to prohibit the application of laws which promote an economic incentive to recover $\mathrm{UCH}$.

\section{UCHC and UNCLOS: non-prejudice, contextualization and consistency}

The relationship between UCHC and UNCLOS is initially set out in the twelfth preambular paragraph of UCHC which provides that states participating in the UNESCO Conference realized:

the need to codify and progressively develop rules relating to the protection and preservation of $[\mathrm{UCH}]$ in conformity with international law and practice, including the UNESCO Convention on the Means of Prohibiting and Preventing the Illicit Import, Export and Transfer of Ownership of Cultural Property of 14 November 1970, the UNESCO Convention for the Protection of the World Cultural and Natural Heritage of 16 November 1972 and the United Nations Convention on the Law of the Sea of 10 December 1982.

This preamble recognizes that the newly adopted rules conform not only with UNCLOS, but also with UNESCO's other cultural heritage conventions, and 'international law and practice', which might refer to any existing customary rules or treaty with regard to $\mathrm{UCH}$ and, arguably, state or private practice that has become generally accepted. ${ }^{47}$ Conformity suggests a convention that 'complies with or is in accordance with' these existing international laws. ${ }^{48}$ The obligation for a treaty to be in 'conformity' with another treaty is a burdensome one; it means that the earlier treaty has to be modelled after the later or implements it in the strict sense. ${ }^{49}$ If conformity were interpreted in this way, UCHC would need to be modelled after international law and practice and could only

\footnotetext{
${ }^{47}$ B H Oxman, 'The Duty to Respect Generally Accepted International Standards' (1991) 24 NYUJILP 109.

${ }^{48}$ Oxford English Reference Dictionary $\left(2^{\text {nd }}\right.$ ed, 1996) 303.

${ }^{49}$ E Zoller, Droit des relations extérieures (1992) 275.
} 
contain provisions derived from them. This is neither what was envisaged at the UNESCO Conference that drafted the UCHC nor what is signified by the phrase 'progressively develop'. This is not what is suggested by the text of the UCHC itself which formulates the relationship between UCHC and UNCLOS in Article 3 as follows:

Nothing in this Convention shall prejudice the rights, jurisdiction and duties of States under international law, including the United Nations Convention on the Law of the Sea. This Convention shall be interpreted and applied in the context of and in a manner consistent with international law, including the United Nations Convention on the Law of the Sea.

The relationship between UCHC and UNCLOS is therefore governed by three related criteria: non-prejudice, contextualization and consistency. ${ }^{50}$

On its face, the non-prejudice formula means that UCHC does not affect, or intend to modify, rights and duties that states otherwise have under international law, including UNCLOS. The French text, for example, is clear to that effect: 'Aucune disposition de la présente Convention ne porte atteinte [i.e. strikes a blow at, undermines, prejudices]'; so, too, is the official Spanish version: 'Nada de lo dispuesto en esta Convención menoscabará [i.e. harms, damages]'. Such a provision is found in other instruments. Article 75 of the Vienna Convention on the Law of Treaties (VCLT) indicates that: ' $t$ t]he provisions of the present Convention are without prejudice to any obligation in relation to a treaty which may arise for an aggressor State in consequence of measures taken in conformity with the Charter of the United Nations'. The Commentary to the draft Articles adopted by the International Law Commission (ILC) indicates that that provision constitutes a reservation formulated in entirely general terms. ${ }^{51}$ When the ILC drafted what formed the basis of Article $73^{52}$ it commented: " $t$ ] he Commission

\footnotetext{
${ }^{50}$ Art 31 of the Vienna Convention on the Law of Treaties, 1155 UNTS 331, 23 May 1969 provides that for the purpose of the interpretation of a treaty, the context comprises the preamble which is deemed included in the text. The terms of a treaty are interpreted in their context and in light of its object and purpose.

${ }^{51}$ ILC Ybk 1966/II, 268.

${ }^{52}$ VCLT Art 73 reads: ' $[$ t]he provisions of the present Convention shall not prejudge any question that may arise in regard to a treaty from a succession of States or from the international responsibility of a State or from the outbreak of hostilities between States', while Art 69 of ILC Draft is worded as follows: '[t]he provisions of the present Arts are without prejudice to any question that may arise in regard to a treaty from a succession of States or from the international responsibility of a State' (emphasis added).
} 
felt that considerations of logic and of the completeness of the draft Articles indicated the desirability of inserting a general reservation covering cases of succession and cases of state responsibility. ${ }^{53}$

The rights, jurisdiction and duties of states parties under UNCLOS remain applicable between such parties to UNCLOS as are also parties to UCHC. ${ }^{54}$ However, while UNCLOS sets out such rights, jurisdiction and duties, it also envisages that other conventions and international agreements, including subsequent conventions and agreements, might touch on such rights, jurisdiction and duties. Indeed, Article 311 of UNCLOS provides that:

2. This Convention shall not alter the rights and obligations of States Parties which arise from other agreements compatible with this Convention and which do not affect the enjoyment by other States Parties of their rights or the performance of their obligations under this Convention.

3. Two or more States Parties may conclude agreements modifying or suspending the operation of provisions of this Convention, applicable solely to the relations between them, provided that such agreements do not relate to a provision derogation from which is incompatible with the effective execution of the object and purpose of this Convention, and provided further that such agreements shall not affect the application of the basic principles embodied herein, and that the provisions of such agreements do not affect the enjoyment by other States Parties of their rights or the performance of their obligations under this Convention.

[...]

5. This Article does not affect international agreements expressly permitted or preserved by other Articles of this Convention.

The non-prejudice formula in Article 3 of UCHC must therefore be read together with Article 311 of UNCLOS to the effect that: (a) UNCLOS may expressly allow

\footnotetext{
${ }^{53}$ Above $\mathrm{n} 51$.

${ }^{54}$ The non-prejudice clause is also known as disconnection clause and is notably used in agreements to which the European Union $(E U)$ is a party. Its purpose is to ensure the continuing application of EU law between EU members without any intent to affect obligations between member states and other parties to the treaty. M Koskenniemi 'Fragmentation of International Law: Difficulties Arising from the Diversification and Expansion of International Law: Report of the Study Group of the International Law Commission', A/CN.4/L.682, 13 April 2006, 148.
} 
for a matter to be regulated by an international agreement as lex specialis; (b) UNCLOS allows for its parties to conclude inter se agreements modifying UNCLOS under certain conditions; and (c) UNCLOS does not prejudice agreements that are compatible with it and do not affect the rights and obligations of other parties to UNCLOS. It is submitted that the relation between Article 3 of UCHC and Article 311 of UNCLOS cannot be narrowly interpreted. A narrow interpretation might suggest that the rights, jurisdiction and duties referred to are the substantive provisions of UNCLOS, excluding Article 311 which contains relational norms, so that UCHC cannot fall within the scope of agreements that Article 311 intends to deal with. A broader interpretation suggests that the right of states, e.g. to modify the operation of provisions of UNCLOS, applicable solely to the relations between them, is a right under UNCLOS, and therefore one which is recognized in Article 3 of UCHC. In light of the preamble's recognition that UCHC also constitutes progressive development of existing international law, this broader interpretation is justified.

So far as UCH is concerned, the international agreements referred to in Article 303(4) are those which Article 311(5) is meant to apply to. Under Article 303(4), this Article is without prejudice to other international agreements and rules of international law regarding the protection of objects of an archaeological and historical nature'. The first paragraph of Article 303 deals with the general duty to protect $\mathrm{UCH}$; the second paragraph covers the coastal state's powers in its contiguous zone and the third paragraph reserves the laws of salvage, admiralty, cultural exchanges and the rights of identifiable owners. In light of the fact that Article 311(5) provides that 'this Article does not affect international agreements expressly permitted or preserved by other Articles of this Convention', this suggests that the 'non-prejudice' test in 311(3) is inapplicable to UCHC as an agreement 'regarding the protection of objects of an archaeological and historical nature'. This would allow for alterations of rights, jurisdiction and duties in relation to the protection of objects of an archaeological and historical nature, namely the powers of the coastal state in its contiguous zone and the rights of identifiable owners and the laws of salvage, as these are addressed in Article 303. However, since Article 303(4), like 303(1), is not limited in its scope by the content of Article 303(2) and Article 303(3), this might have broader implications, unless one considers that Article 3 of UCHC and Article 303(4) cancel each other out. In this case, Article 3 of the UCH itself provides the mechanism for conflict avoidance, for it requires that the UCHC be interpreted and applied in the context of and in a manner consistent with UNCLOS in particular, and international law generally. 
The term 'consistent' is different from the strict conformity test identified above. It suggests that UCHC be 'in harmony' with UNCLOS, or 'not contradict' it. ${ }^{55}$ 'Consistency' here means compatibility and compatibility denotes norms that must not be in conflict with one another, that is, norms that may be simultaneously applied. The consistency clause in Article 3 of UCHC, which is used as a guiding principle of the interpretation and application of the UCHC as a whole, is also known as the principle of harmonization or systemic integration. Under that principle, when several norms bear on a single issue they should, to the extent possible, be interpreted so as to give rise to a single set of compatible obligations. ${ }^{56}$ Interpretation here partakes in the process of conflict avoidance, for "[w]hether there is a conflict and what can be done with prima facie conflicts depends on the way the relevant rules are interpreted ... Interpretation does not intervene only once it has already been ascertained that there is a conflict. Rules appear to be compatible or in conflict as a result of interpretation. ${ }^{\prime 5}$ However, unlike Article 31(3)(c) of the Vienna Convention which requires that relevant rules of applicable international law be 'taken into account', Article 3 requires that the UCHC be interpreted consistently with UNCLOS (not the other way around). This type of consistency clause therefore appears to operate on the basis of a hierarchical (or quasi-hierarchical) relation between the two instruments. The formula set out in Article 3 of UCHC is not unique, and is also present, for example, in the 1995 UN Fish Stocks Agreement (1995 Agreement), ${ }^{58}$ which in Article 4 provides that 'nothing in this Agreement shall prejudice the rights, jurisdiction and duties of States under the Convention. This Agreement shall be interpreted and applied in the context of and in a manner consistent with the Convention'. The 1995 Agreement notably indicates that only those states which intend to fish on the high seas which are members of such a regional fisheries management organization or participants in such an arrangement, or which agree to apply the conservation and management measures established by such organization or arrangement, shall have access to the fishery resources to which

\footnotetext{
${ }_{55}$ Oxford English Reference Dictionary (2 ${ }^{\text {nd }}$ ed, 1996) 307.

${ }^{56}$ Conclusions of the work of the Study Group on the Fragmentation of International Law: Difficulties arising from the Diversification and Expansion of International Law, <http://untreaty.un.org $>$ [accessed 7 January 2013]; Right of Passage over Indian Territory (Portugal v India), Preliminary Objections, ICJ Reports 1957 p 21; see Art 31(3)(c) of the Vienna Convention.

${ }^{57}$ Koskenniemi, above n 54, 207.

${ }^{58}$ The United Nations Agreement for the Implementation of the Provisions of the United Nations Convention on the Law of the Sea of 10 December 1982 relating to the Conservation and Management of Straddling Fish Stocks and Highly Migratory Fish Stocks, 8 September 1995, 2167 UNTS 3.
} 
those measures taken in relation to straddling fish stocks and highly migratory fish stocks apply. ${ }^{59}$ While this seriously curtails the traditional right to fish on the high seas, UNCLOS itself subjects that right to the duty to take measures for their respective nationals as may be necessary for the conservation of the living resources of the high seas. ${ }^{60}$ This is how the 1995 Agreement implements UNCLOS. ${ }^{61}$ Thus the Study Group on Fragmentation of International Law found that, in the relation between a general and a specific treaty, the characterization of the latter as lex specialis or lex posterior may not all lead to the setting aside of the general treaty; instead, that earlier and general instrument may remain 'in the background', controlling the way the later and more specific rules are being interpreted and applied. ${ }^{62}$ Only a few provisions in UNCLOS are expressly relevant to the protection of $\mathrm{UCH}$ and these are either too vague to be prejudiced by the UCHC (i.e. provisions on the Area) or they specify that UCHC is not prejudiced by them (Article 303(4)) or they indicate that UNCLOS may be modified in certain circumstances or that compatible agreements are not altered by UNCLOS (Article 311(2) and (3)). In that sense, it can hardly be contended that UCHC is an 'implementing' agreement of UNCLOS in relation to UCH. ${ }^{63}$ While UCHC is conceived of as an instrument that will develop rules on $\mathrm{UCH}$ within the controlling framework of UNCLOS, relations of a strict normative hierarchy between the UCHC and UNCLOS can really only be envisaged to the extent that the UCHC must be compatible with UNCLOS under Article 311(2). Such compatibility is required by Article 3 of the UCHC in its interpretation and application. Under UCHC, if it is impossible to interpret it in a manner consistent with UNCLOS, the rights and duties of states under UNCLOS take priority, as they must remain unaffected (non-prejudiced) by UCHC. As argued above, these rights contain the right to modify UNCLOS under Article 311(3) provided the effective execution of the object and purpose of UNCLOS and its basic principles are not affected by the modification. While this is in itself a

\footnotetext{
${ }^{59}$ Art 8(4) of the 1995 Agreement.

${ }^{60}$ UNCLOS Art 117.

61 The approach taken by the 1994 Agreement relating to the implementation of UNCLOS Part XI substantially modifies UNCLOS regime of deep sea bed mining and does so outside the procedures established by UNCLOS itself, for UNCLOS was not in force when the Agreement was adopted. It specifies that it will prevail over UNCLOS in the event of inconsistency (Art 2(1)).

${ }^{62}$ Koskenniemi, above $\mathrm{n} 54,22$. The lex posterior rule is reflected in the type of conflict-resolution solution that the Vienna Convention envisages for successive treaties on the same subject-matter in Art 30(3); the general principle lex specialis is considered by the Study Group on Fragmentation of International Law a generally accepted technique of conflict resolution: above n 56, para 5.

${ }^{63}$ Gonzalez, above n 4, 118.
} 
question of interpretation, ${ }^{64}$ it seems in this context that the modifying inter se agreement must not jeopardize the collective interests embodied in an instrument that purports to achieve a regime for the oceans. Within those limits it appears, as argued by the Study Group which examined Article 311(3), that

'compatibility' has been formulated rather loosely. Parties are given a wide latitude to conclude agreements on topics dealt with by the UNCLOS with only the caveat that this should not 'affect the application of basic principles' or the 'rights' and 'obligations' of the [other] parties. Although there is room to interpret the expressions 'rights' and 'obligations' either more or less strictly, the thrust of the provision lies in a search for reasonable accommodation [...] [I]t seems to look for a 'mutually supporting' role for the UNCLOS and those particular instruments. ${ }^{65}$

It is therefore unnecessary to seek in Article 303(4) an interpretation that exempts the whole of UCHC from the scope of Article 311 via its paragraph 5, for this is not the result intended in Article 3 of UCHC. In that respect, it must be distinguished between provisions in the UCHC which may be unwelcome by a certain number of states (which therefore refuse to become parties to UCHC) and provisions in UCHC which are not compatible with UNCLOS. A provision which is incompatible with UNCLOS is, quite clearly, one which cannot be interpreted in a manner consistent with UNCLOS and, therefore, one which prejudices rights that states have under UNCLOS in contradiction of Article 3. As stated above, a UCHC provision will not be inconsistent with UNCLOS if UNCLOS itself allows a measure of contrariety between the two instruments. In addition, a UCHC provision will not be inconsistent with UNCLOS if UNCLOS does not definitely attribute the relevant rights. Lastly, it should also be recalled that a provision of UCHC need not be in strict conformity with UNCLOS in order to be consistent with it.

\footnotetext{
${ }^{64}$ VCLT Art 41.

${ }^{65}$ Koskenniemi, above n 54, 142.
} 


\section{UNCLOS's maritime zones and UCHC}

\subsection{Internal waters, archipelagic waters and territorial sea}

While original intent of the UCHC was to provide some measure of protection for UCH found beyond states' jurisdiction, there was a view that it should require states parties to ensure that the UCH in the internal waters, archipelagic waters and territorial seas be protected to the same minimum standards. ${ }^{66}$ Whilst recognising that states have, in the exercise of their sovereignty, the exclusive right to regulate and authorize activities directed at $\mathrm{UCH}$ in these maritime zones, ${ }^{67}$ the UCHC requires states to apply the Annexed Rules to such activities. ${ }^{68}$ This is entirely consistent with UNCLOS.

Within these maritime zones of many states lie the wrecks of foreign warships. ${ }^{69}$ Article 7(3) of UCHC provides that:

in the exercise of their sovereignty and in recognition of general practice among States, States Parties, with a view to cooperating on the best methods of protecting State vessels and aircraft, should inform the flag State party to this Convention and, if applicable, other States with a verifiable link, especially a cultural, historical or archaeological link, with respect to the discovery of such identifiable State vessels and aircraft.

A number of maritime states were concerned that, if they were to become parties, the effect of Article 7 would be to undermine their sovereign rights to their sunken warships. ${ }^{70}$ Articles 95 and 96 of UNCLOS recognise the absolute immunity from jurisdiction of warships and state owned or operated vessels used only

\footnotetext{
${ }^{66}$ Doc CLT-96/CONF.202/5 Paris, April 1998, 8; Doc CLT-99/WS/8, 28. See Dromgoole, above $\mathrm{n}$ $4,116$.

${ }^{67}$ UCHC Art 7(1).

${ }^{68} \mathrm{UCHC}$ Art $7(2)$.

${ }^{69}$ A number of instances have occurred where coastal state jurisdiction and flag state ownership and jurisdiction have clashed. These include the wreck of the HMS Birkenhead, a United Kingdom vessel sunk in South African territorial sea; the CSS Alabama, as an United States vessel sunk in French territorial sea, the Juno and La Galga, Spanish vessels sunk in United States territorial sea; the La Belle, a French vessel sunk in US territorial sea, the HMS Spartan, a UK vessel sunk in Italian territorial sea and the Admiral Nakhimov, a captured Russian vessel sunk in Japanese territorial sea. Forrest, above n 8, 46-8; J A Roach, 'Sunken Warships and Military Aircraft' (1996) 20 Marine Policy 351.

${ }^{70}$ Dromgoole, above n 4, 5.
} 
on governmental service. This immunity is extended to the salvage of such vessels. ${ }^{71}$ Nevertheless, uncertainty does exist as to the customary international law applicable to a number of issues, including abandonment of ownership or sovereign rights. ${ }^{72}$ The UCHC, however, does not address these issues. Article 2(8) says that ' $[\mathrm{c}]$ onsistent with State practice and international law, including the United Nations Convention on the Law of the Sea, nothing in this Convention shall be interpreted as modifying the rules of international law and State practice pertaining to sovereign immunities, nor any State's rights with respect to its State vessels and aircraft. ${ }^{73}$ This qualification to Article 7(3), which merely exhorts the coastal state to inform the flag state of the discovery of such identifiable state vessels and aircraft in these maritime zones under its sovereignty ensures that UNCLOS, and other applicable international law, continues to govern these issues. As such, no inconsistency with UNCLOS arises. ${ }^{74}$

\subsection{Contiguous zone}

The UCHC provides, in Article 8, that 'States Parties may regulate and authorize activities directed at underwater cultural heritage within their contiguous zone. In so doing, they shall require that the Rules be applied'. Importantly, Article 8 further provides that states may only do so 'in accordance with' Article 303(2) of UNCLOS. Article 303(2) relates to the 'removal from the seabed' of objects of an archaeological and historical nature and will not cover activities such as diving on, filming, or in some way damaging the wreck. ${ }^{75}$ In permitting a coastal state to 'regulate and authorise activities directed at UCH', the state gains greater regulatory jurisdiction than Article 303(2) confers on it, as it allows the coastal state to not merely regulate the 'removal from the seabed' of $\mathrm{UCH}$, but any activity

${ }^{71} 1910$ International Convention for the Unification of Certain Rules with Respect to Assistance and Salvage at Sea and Protocol of Signature, 23 September 1910, [1913] UKTS 4; International Convention on Salvage, 28 April 1989, 1953 UNTS 165.

${ }^{72}$ M J Aznar-Gómez, 'Treasure Hunters, Sunken State Vessels and the 2001 UNESCO Convention on the Protection of Underwater Cultural Heritage' (2010) 25 International Journal of Marine and Coastal Law 209.

${ }^{73}$ State vessels are defined in UCHC Art 1(8) as 'warships, and other vessels or aircraft that were owned or operated by a State and used, at the time of sinking, only for government non-commercial purposes, that are identified as such and that meet the definition of underwater cultural heritage'. See UNCLOS Art 29.

${ }^{74}$ The same applies with respect to sovereign vessels found on the EEZ and continental shelf. See UCHC Art 10(7).

${ }^{75}$ Newton, above n 8, 187; Migliorino, above n 8, 486. 
'directed at' UCH. Nevertheless, this is consistent with UNCLOS on the strength of Articles 303(4) and 311(5).

\subsection{The continental shelf and exclusive economic zone}

The Geneva Convention on the Continental Shelf ${ }^{76}$ recognises the coastal state's sovereign rights for the purposes of exploring and exploiting the natural resources of the CS. The travaux préparatoires and the $\mathrm{ILC}^{77}$ indicate that the 'natural resources' of the continental shelf do not include $\mathrm{UCH}^{78}$ As such, coastal states do not have exclusive power to regulate the search for, or recovery of, $\mathrm{UCH}$ on the CS. However, since UCH is inevitably imbedded in the seabed or relatively quickly integrated into the living landscape, coastal states have exclusive jurisdiction over $\mathrm{UCH}$ to the extent that the disturbance of the seabed may impact on a coastal state's rights on the CS. ${ }^{79}$

Article 77 of UNCLOS is almost identical to that of Article 2 of the Geneva Convention, limiting the exclusive rights of the coastal state to the exploration and exploitation of the natural resources of the CS. This does not include $\mathrm{UCH} .{ }^{80}$ This includes the search for $\mathrm{UCH},{ }^{81}$ as it is excluded from the regime of marine scientific research. ${ }^{82}$ It is likely, however, that the coastal state can regulate both the search for and recovery of UCH to the extent that these activities do impact

${ }^{76}$ Geneva Convention on the Continental Shelf, 29 April 1958, 499 UNTS 311, Art 2.

${ }^{77}$ Report of the International Law Commission Covering the Work of its Eighth Session, 1956 ILC Ybk 1956/II. See Treasure Salvors, Inc v Unidentified, Wrecked and Abandoned Sailing Vessel, 569 F 2d 330,340 ( $5^{\text {th }}$ Cir, 1978).

${ }^{78}$ See Strati, above n 7, 249-50; Caflisch, above n 12, 14; A Korthals Altes, 'Submarine Antiquities: A Legal Labyrinth' (1976) 4 Syracuse Journal of International Law and Commerce 77, 80; J K Meenan, 'Cultural Resource Presentation and Underwater Archaeology' (1978) 15 San Diego Law Review 623, 644; F M Auburn, 'Convention for Preservation of Man’s Heritage in the Ocean' (1974) 185 Science 763, 764.

${ }^{79}$ Strati, above n 7, 257.

${ }^{80}$ Ibid, 262. Contra E M Fry, 'Synopsis. Recent Developments in the Law of the Sea 1984-1985' (1986) 23 San Diego Law Review 701, 720-2; D E Cycon, 'Legal and Regulatory Issues in Marine Archaeology' (1985) 28 Oceanus 78. Some states have extended their heritage legislation to cover the CS, including Australia (Historic Shipwrecks Act 1976), Ireland (National Monuments (Amendment) Act 1987), Seychelles (Maritime Zones Act 1977), Cyprus (Law No 4 of 1974), Norway (Section 44 of the Royal Decree of 8 December 1972) and Portugal (Law No 289/93 of 21 August 1995).

${ }^{81}$ UNCLOS Art 246(2).

${ }^{82}$ See, however, S Dromgoole, 'Revisiting the relationship between marine Scientific research and the Underwater Cultural Heritage' (2010) 25 International Journal of Marine and Coastal Law 33. 
on its exclusive rights as provided for in UNCLOS. ${ }^{83}$

Unless expressly provided for in convention ${ }^{84}$ or customary law, the content of the freedom of the high seas may arguably operate on the basis of a presumption. Thus it has been held that the search for and recovery of UCH on the CS is an exercise of the freedom of the high seas. ${ }^{85}$ It is submitted that if jurisdiction over an activity is not exclusively attributed to a specific state, if it does not breach an existing rule of international law, and if it does not hamper the exercise by other states of their freedom of the high seas, then that activity is a freedom of the high seas. ${ }^{86}$ If it is a freedom of the high seas, then it may be exercised by any state with due regards for the rights of other states. ${ }^{87}$ That right can then be implemented, or restricted, or denied by agreement between the parties concerned. Indeed, even when an activity is recognized as a high seas freedom, its scope may be restricted by agreement and an activity previously considered a freedom of the high seas may be withdrawn from the freedom of the high seas; such would be the case for deep seabed mining under the UNCLOS, at least if one follows the views of the US and many developed States that deep seabed mining was a freedom of the high seas.

In the EEZ, Article 56 provides that the coastal state has sovereign rights 'for the purpose of exploring and exploiting, conserving and managing the natural resources, whether living or non-living, of the water superadjacent to the sea-bed and of the sea-bed and subsoil'. ${ }^{88}$ Moreover, the coastal state also has jurisdiction in relation to the establishment and use of artificial islands, installations and

\footnotetext{
${ }^{83}$ This might also include the exclusive right of the coastal state to conduct and to authorise the construction operations in the EEZ and CS (UNCLOS Arts 60 and 80 ) and to authorise and regulate drilling on the CS (UNCLOS Art 81).

${ }^{84}$ UNCLOS Art 87(1). The argument may also be made that an activity may be included within an activity that is explicitly recognised as a freedom of the high seas. Thus the freedom to bunker is included in the freedom of navigation.

${ }^{85}$ Caflisch above n 12, 25; Oxman, above n 13, 357.

${ }^{86}$ E.g. ILC Ybk 1956/II, 278; R R Churchill \& A V Lowe, The Law of the Sea (1988) 166; S N Nandan \& S Rosenne (eds), United Nations Convention on the Law of the Sea 1982. A Commentary, vol 3 (1995) $84-5$. One could consider that such initial presumption gives weight to the exercise by a State of an activity that is claimed to be a freedom of the high seas. Such a claim might be rejected by other users as being impermissible: see notably M S McDougal and W T Burke, The Public Order of the Oceans (1962) 752-3. From this series of claims and counterclaims would thus emerge a customary rule that the purported activity is unlawful: e.g. M S McDougal \& N E Schlei, "The Hydrogen Bomb Test in Perspective: Lawful Measures for Security' (1954-55) 64 Yale LJ 648.

${ }^{87}$ UNCLOS Art 87(2).

${ }^{88}$ UNCLOS Art 56(1)(a). Art 56(3) provides that the seabed of the EEZ is governed by Part VI on the CS.
} 
structures, marine scientific research, and the protection and preservation of the marine environment. ${ }^{89}$ Although Article 56 includes 'other activities for the economic exploitation and exploration of this zone', they are limited to the natural features of the zone. Research and recovery of UCH does not fall within these rights and, therefore, must be considered a freedom of the high seas preserved under Article 58(1). ${ }^{90}$ As such, the powers of the coastal state to regulate the recovery of UCH will depend upon the impact these activities have on the resources of the EEZ.

If the view is advanced that research and recovery of $\mathrm{UCH}$ in the EEZ is not a preserved freedom of the high seas, and to the extent that these activities do not fall within the coastal states jurisdiction, then Article 59 is applicable. ${ }^{91}$ It may be argued that where conflicts arise on issues not involving the exploration for and exploitation of resources, Article 59 would tend to favour the interests of other states or of the international community as a whole. ${ }^{92}$ Nevertheless, nothing prevents states by agreement from re-shifting that balance towards

\footnotetext{
${ }^{89}$ UNCLOS Art 56(1)(b).

${ }^{90}$ Both Jamaica and Morocco regulate UCH in the EEZ: see Moroccan Decree No 181179 of 8 April 1981 and Jamaican Exclusive Economic Zone Act 33 of 1991. Such an interpretation would only be consistent with the powers of the coastal state in the EEZ if UNCLOS Art 56(1)(c) were interpreted as including a right the coastal state may derive from other international agreements entered into under Art 311.

${ }^{91}$ UNCLOS Art 59 provides that:
}

\begin{abstract}
in cases where this Convention does not attribute rights or jurisdiction to the coastal State or to other States within the exclusive economic zone, and a conflict arises between the interests of the coastal state and any other state or states, the conflict should be resolved on the basis of equity and in the light of all the relevant circumstances, taking into account the respective importance of the interests involved to the parties as well as to the international community as a whole.

The view may be held that Art 59 only applies when the UNCLOS 'as a whole' does not attribute an activity either to the coastal State or to third States in the EEZ. For Oxman, since Art 303(2) expressly attributes rights to the coastal state within waters forming part of the EEZ, it would appear that Art 59 should not be read to apply to marine archaeology. Oxman, above n 13, 369. A liberal view of Art 59 would make its applicability dependent upon the absence of express attribution of an activity to the coastal state or third states. A stricter approach will only turn to Art 59 when allocation of an activity to the coastal State or to third States may not be made expressly or impliedly.
\end{abstract}

${ }^{92}$ S N Nandan \& S Rosenne, United Nations Convention on the Law of the Sea 1982; A Commentary, vol 2 (1993) 569. 
greater coastal state control. It could be argued that the UCHC does that in some provisions of Articles 9 and 10.

The UCHC regime is underpinned by a system for the reporting and notification of $\mathrm{UCH}$ in the EEZ and on the CS (Article 9) and for the protection of such UCH (Article 10). With regard to notification and reporting, a complex system is structured to ensure that all interested states will be notified of the discovery of, or plans to undertake any activities directed at, $\mathrm{UCH}$ in these maritime zones. Coastal states are required to ensure that their nationals or vessels flying their flag report finds or intended activities to it. ${ }^{93}$ States whose nationals or flag vessels find or intend to undertake activities directed at $\mathrm{UCH}$ on another state's CS or EEZ are required to report to its competent authorities and to the authorities of the coastal state. Alternatively, the other states need only require that the report be made to it, and it undertakes to inform the coastal state. ${ }^{94}$ States are then bound to inform the Director-General of UNESCO of any finds or reports of intended activities directed at $\mathrm{UCH}$, who in turn informs all other states of any reports received. ${ }^{95}$ Any state with a verifiable link, especially a cultural, historical or archaeological link with the UCH in question, may then declare its interest in being consulted on how the UCH may be effectively protected. ${ }^{96}$

Whilst Articles 9(1)(b)(i) and (ii), in referring to 'the' national and 'the' master rather than 'its' national or master might suggest that the coastal state has jurisdiction to order a foreign national or master to report to it, the preferable interpretation, and which would be consistent with UNCLOS, would restrict such reporting powers to the state of nationality. ${ }^{97}$ Despite being a preferable interpretation, attempts during negotiations to ensure such an interpretation failed, resulting in a 'constructive ambiguity. ${ }^{\prime}$ It appears then that a number of states were eager to require foreign nationals and foreign vessels to report finds, or intended activities, directly to it as the coastal state. This alternative interpretation ${ }^{99}$ might, however, also be consistent with UNCLOS if such coastal

\footnotetext{
${ }_{93}$ UCHC Art 9(1)(a).

${ }^{94}$ UCHC Art 9(1)(b).

${ }^{95}$ UCHC Arts 9(3) and (4).

${ }^{96}$ UCHC Art 9(5).

${ }^{97}$ Commissie van advies inzke volkenrechtelijke vraagstukken, Advisory Report on the UNESCO Convention on the Protection of the Underwater Cultural Heritage, Advisory Report No 21, December 2011, 5-7.

${ }^{98}$ P J O'Keefe, Shipwrecked Heritage: A Commentary on the UNESCO Convention on Underwater Cultural Heritage (2002) 83.

${ }^{99}$ This appears to have occurred, for example, in Norwegian oil and gas exploration permits which
} 
state reporting powers were to be regarded as an implementation of the duty embodied in Article 303(1), and consistent with Article 311(5) of UNCLOS. ${ }^{100}$

Article 10 of UCHC provides for a preservation regime on a coastal state's CS or EEZ. The relationship between this regime and UNCLOS is set out in Article 10(1) that provides that ' $[\mathrm{n}] \mathrm{o}$ authorization shall be granted for an activity directed at underwater cultural heritage located in the exclusive economic zone or on the continental shelf except in conformity with the provisions of this Article', which itself must be consistent with UNCLOS. ${ }^{101}$ Furthermore, Article 10(2) of UCHC provides that a state party in whose EEZ or on whose CS UCH is located has the right to prohibit or authorize any activity directed at such heritage to prevent interference with its sovereign rights or jurisdiction as provided for by UNCLOS. This is merely declaratory of the rights the coastal state has pursuant to Articles 56 and 77 of UNCLOS, and ensures the primacy of UNCLOS. Together, these preliminary sub-sections set out to achieve a foundation for a regime that is consistent with UNCLOS.

The preservation regime itself is underpinned by state cooperation. Article 10(3) provides that where there is a discovery of $\mathrm{UCH}$, or it is intended that activity shall be directed at UCH in a state party's EEZ or on its CS, that state party shall consult all other states parties which have declared an interest under Article 9(5) on how best to protect the $\mathrm{UCH} .{ }^{102}$ The coastal state is expected then to take the lead in this cooperative undertaking and to coordinate such consultations as 'Coordinating State'. Importantly, it is not necessary that the coastal state takes on such a role, although it is the default option that will arise by operation of the convention. If the coastal state expressly declares that it does not wish to act as Coordinating State, then the states parties which have declared an interest shall appoint a Coordinating State. ${ }^{103}$

The Coordinating State, which may not necessarily be the coastal state, 'shall implement measures of protection which have been agreed by the consulting states $^{\text {'104 }}$ and 'shall issue all necessary authorizations for such agreed measures

\footnotetext{
have required the foreign permit holder to report finds of underwater cultural heritage on the Norwegian continental shelf to Norway: ibid, 81 .

${ }^{100}$ Above n 95, 8 .

${ }^{101} \mathrm{UCHC}$ Art 3.

${ }^{102}$ UCHC Art 10(3)(a).

${ }^{103}$ UCHC Art 10(3)(b). A coastal state may, for example, not wish to devote resources to the investigation of a wreck that has little link with the coastal state, and relate it to the state of cultural origin, for example, to coordinate the protective regime. See O'Keefe, above n 97, 91.

${ }^{104}$ UCHC Art 10(5)(a).
} 
in conformity with the Rules. ${ }^{105}$ Both implementation and authorisation can be undertaken by a state other than the Coordinating State. ${ }^{106}$ It is quite possible then that the coastal state is neither the Coordinating State nor the state that implements protective measures and authorises activities directed as UCH. This is unlikely though, as one would expect the coastal state might want to take on the role of Coordinating State given its sovereign interests in these zones.

It is the role of the coastal state as the chosen Coordinating State to take action when $\mathrm{UCH}$ is in immediate danger or to conduct preliminary research prior to consultation that may cause some concern. Article 10(4) provides that the 'Coordinating State may take all practicable measures, and/or issue any necessary authorizations in conformity with this Convention and, if necessary prior to consultations, to prevent any immediate danger to the underwater cultural heritage, whether arising from human activities or any other cause, including looting'. Similarly, the Coordinating State 'may conduct any necessary preliminary research on the underwater cultural heritage and shall issue all necessary authorizations therefore ${ }^{107}$ Whilst the Coordinating State may not be the coastal state, in these circumstances it will most likely be the coastal state, especially if any actions are taken prior to consultation. Nevertheless, it is clear that this is not itself an exclusive grant of powers to the coastal state. This is further emphasised in Article 10(6), which declares that in 'coordinating consultations, taking measures, conducting preliminary research and/or issuing authorizations pursuant to this Article, the Coordinating State' shall act on behalf of the States Parties as a whole and not in its own interest.

Since the Coordinating State is not necessarily the coastal state, the implementation of protective measures and authorisations is not, in itself, an extension of the rights and duties of the coastal state as provided for in UNCLOS. The coastal state only has the power to unilaterally prevent or authorise activities directed at $\mathrm{UCH}$ on its CS or EEZ zone in order to prevent interference with its sovereign rights and jurisdictions. ${ }^{108}$ Admittedly, this is more likely to be the case than not given the very close relationship between $\mathrm{UCH}$ and the resources of the EEZ and CS.

Nevertheless, the possibility of the coastal state having such powers may have created a shift in the balance between coastal states and flag states. If Article 58 of UNCLOS does not include the freedom to conduct archaeological research

\footnotetext{
${ }^{105}$ UCHC Art 10(5)(b).

${ }^{106} \mathrm{UCHC}$ Arts 10(5)(a) and (b).

${ }^{107}$ UCHC Art 10(5)(c).

${ }^{108}$ UCHC Art 10(2).
} 
or recovery in another state's EEZ and Article 56 does not grant the coastal state regulatory rights over $\mathrm{UCH}$ in its EEZ, then the resulting conflict is to be resolved in accordance with Article 59, and the UCHC favours the coastal state when it is the Coordinating State. This shift, however, is merely a function of the obligation arising from Article 303(1) of UNCLOS underpinned by the cooperative nature of the preservation regime introduced. ${ }^{109}$ The UCHC may therefore be interpreted in a manner which does not give rise to incompatible obligations, and is thus consistent with UNCLOS.

\subsection{The Area}

Like Article 10, Article 11 begins by laying an UNCLOS foundation for the protective regime in the Area ${ }^{110}$ by declaring that states parties have a responsibility to protect $\mathrm{UCH}$ in the Area in conformity with this Convention and Article 149 of UNCLOS. Whilst the latter is difficult to interpret, it nevertheless imposes a duty which is given content by UCHC.

The system for reporting, notification and implementation of the preservation regime is similar to that applicable to the EEZ and CS except that as there will not be a coastal state to assume the role of Coordinating State, all states which have expressed an interest in being a party to a protective regime will elect one state to act as the Coordinating State. ${ }^{111}$ The reporting obligation merely necessitates that states parties require that a national, or a vessel flying its flag reports any discovery or intent to engage in activities directed at UCH located in the Area to it. ${ }^{112}$ This is entirely consistent with states' rights in international law and UNCLOS. So too is the coordinated protective regime, which rests entirely on each state's jurisdictional capacity to regulate vessels flying its flag and its nationals. ${ }^{13}$

\section{Conclusion}

The drafting of the UCHC was undertaken in a context in which states sought consistency with UNCLOS, resulting not only in its substantive content but in the articulation of consistency in Article 3. Consistency stricto sensu may

\footnotetext{
${ }^{109}$ Above n 96, 10.

${ }^{110}$ UNCLOS Art 1(a) states that, for the purposes of the convention, the 'Area' means 'the seabed and ocean floor and subsoil thereof, beyond the limits of national jurisdiction'.

${ }^{111}$ UCHC Arts 11 and 12.

${ }^{112}$ UCHC Art 11(1).

${ }^{113}$ UCHC Art 12(3).
} 
mean consistency with UNCLOS's jurisdictional framework. In this respect, the UCHC may not be entirely consistent, although the resulting inconsistencies are rather minor and often subject to alternative interpretations. When two interpretations are possible, the preferred one is that which is consistent with UNCLOS's existing jurisdictional framework, notwithstanding Article 303(4) and 311, as exemplified in the interpretation of Article 9(1)(b)(ii) of UCHC.

Consistency lato sensu, however, must take account of the adaptive nature of UNCLOS provided for in Article 303(4) and 311. In light of the negotiations of UCHC in a context that sought consistency with UNCLOS specifically through reference to Article 303(4), the mechanisms inherent in Article 311 clearly support the UCHC regime and make it consistent with UNCLOS. As such, while some aspects of UCHC may be unwelcome by certain states (which therefore refuse to become parties to the UCHC), the UCHC is consistent with UNCLOS, and no international barrier exists that hinders broad state participation in this important protective regime. 